\title{
Alguns aspectos da sexualidade no judaísmo
}

Arnaldo Risman*

\section{INTRODUÇÃO}

$\mathrm{Na}$ literatura corrente relacionada à sexualidade, observa-se a falta de conteúdos sobre a religião judaica. Por este motivo, resolvemos realizar uma pesquisa bibliográfica utilizando as obras consideradas básicas pela religião, como Torá (1312 A.C.), Mishná (242 D.C.), Talmud de Jerusalém (342 D.C. a 392 D.C.) e da Babilônia (500 D.C.), Shulchan Aruch (1480 D.C.) e Zohar (1522 D.C. e 1570 D.C.), entre outras, obras estas escritas em hebraico e aramaico, o que dificulta a leitura por paste dos leigos.

Enfocamos alguns conceitos que geram distorções em nossa sociedade: menstruação, purificação espiritual, sexo e relação sexual no Judaísmo. Tentamos esclarecer estes conceitos para que o leitor tenha maiores conhecimentos sobre a sexualidade no Judaísmo.

* Psicólogo Clínico. Pós-graduado em sexualidade Humana pela Universidade Gama Filho, Recebido em 16.03.96 Aprovado em 26.03.96 


\section{MENSTRUAÇÃO: ESCLARECENDO CONCEITOS}

Entre os mandamentos mais difíceis de se entender nos conceitos judaicos está o da menstruação.

Segundo a Torá (Velho Testamento), o ser humano após o pecado original adquiriu algumas imperfeições. Entre elas está o sexo e a reprodução.

Para os sábios judeus do Talmud da Babilônia, a menstruação faz parte dessas imperfeições, Segundo eles, o óvulo deveria ser reabsorvido pelo organismo quando não fecundado, a não ser eliminado, tornando-se um incômodo para a mulher mensalmente. (Kaplan, 1992)

De acordo com o conceito judaico, do primeiro dia do ciclo menstrual até o dia do banho ritual de purificação, a mulher judia adquire o status de "NIDDAH". (Kaplan, 1992)

Niddah vem da palavra Naddah, que em hebraico significa "separado". Neste período o casal se "afasta sexualmente".

Segundo a Torá, enquanto houver o fluxo sangüíneo vindo do útero, a mulher não poderá realizar um ato sacgrado que é a relação sexual, já que um dos objetivos é de trazer uma alma para este mundo.

Lamn (1970) relatou que um dos objetivos da separação estaria ligado a dois pontos importantes numa relação: o diálogo e o desejo sexual. Esses fatores aumentam neste período de afastamento.

Ao término do ciclo menstrual a mulher realiza uma exame chamado "Hefsek Taharah", que consiste numa verificação que apura se a menstruação cessou totalmente. Esse exame consta em utilizar um pequeno pano de linho branco, chamado "Ed", no qual a mulher passa no órgão genital. Observando a não existência do sangue, a mulher contará sete dias limpos, como está na Torá: "Ela deverá contar sete dias limpos e depois estará purificada". (Levítico, 15:25). Após a verificação e os sete dias limpos a mulher deverá realizar o banho de purificação.

\section{MICVÊ: UMA MUDANÇA DE STATUS}

A palavra em hebraico micvê significa "piscina" ou "conjunto de água". O único lugar onde o micvê é especificamente definido na Torá é no Versículo: "Somente uma fonte e uma jazida, um conjunto (micvê) de água será puro". (Levítico, 11:36) 
Existem seis condições necessárias que um volume de água deve preencher antes de poder ter o status de micvê. São eles: (1) o micvê deve consistir de água de chuva; (2) o micvê deve ser construido no chão; (3) a água de um micvê não pode estar correndo ou fluindo; (4) a água não pode ser trazida pelo ser humano; (5) a água não pode ser canalizada para o micvê através de canos ou recipiente de metal, argila ou madeira; (6) o micvê deve conter aproximadamente 750 litros de água.

O uso do micvê não se restringe ao banho ritual que a mulher realiza após o período de Niddah. Também é utilizado para a conversão ao Judaísmo, para o homem antes das festas judaicas a para os utensílios utilizados na cozinha.

O objetivo da imersão no micvê é a mudança de status, isto é, de estado de imperfeição para o de perfeição espiritual. Não está ligado a limpeza corporal, já que no caso da mulher ela deve, antes de entrar no micvê, realizar algumas tarefas: lavar o corpo todo, lavar os cabelos, cortar as unhas, retirar o esmalte e realizar as necessidade fisiológicas. Esse banho anterior realizado no banheiro onde se encontra o micvê é para que nenhuma substância interfira na imersão, como está na Torá: "Ela lavará toda sua carne nas águas vivas, e será pura". (Levítico, 15:13)

Após o banho a mulher realiza a imersão no micvê e com a mudança de status estará pronta para as relações sexuais com seu marido.

\section{SEXO E RELAÇÃO SEXUAL NO JUDAÍSMO}

Geralmente, as relações sexuais no Judaísmo iniciam-se com a sedução feminina. A característica fundamental não é a palavra e sim as ações que a mulher realiza para atrair seu parceiro. Essas ações estão ligadas diretamente ao comportamento, isto é, vestimenta, pintura, comida e olhar, entre outras.

Isso a diferencia do homem, que utiliza palavras para a realização do sec desejo.

A relação sexual no Judaísmo é um dos primeiros mandamentos. Assim está na Torá: "O homem deixará seu pai e sua mãe e unir-se-á à sua mulher, tornando-se ambos uma só carne”. (Gênese 2-18-25).

No Judaísmo existem quatro intenções básicas na relação sexual:

(1) cumprir o mandamento de manter relações sexuais com sua esposa e ter filhos: 
(2) cumprir o mandamento de alegrar a esposa tendo relações maritais, dentro de uma certa constância. Into aplica-se também às relações com a esposa mesmo estando grávida;

(3) satisfazer a vontade e o desejo da esposa;

(4) a realização do desejo do homem.

O mandamento de ter relações com a sua esposa é uma das obrigações do marido e um dos direitos da mulher. Esta tensão é considerada louvável por mais que não haja a idéia de reprodução.

A mulher no Judaísmo, quando por algum motivo não se adapta sexualmente com o seu parceiro, poderá pedir divórcio, já que um dos Objetivos da relação sexual é o prazer.

De acordo com Rabbi Eliahu (1984), a obrigação de dar prazer a esposa não se aplica somente no caso da relação sexual mas sim em qualquer situação. $\mathrm{O}$ autor ainda comenta que existe a proibição de se recusar em ter relações sexuais com sua esposa com o intuito de causar-lhe sofrimento ou frustração. Nem forçá-la a ter relações, pois um don mandamentos existentes no Judaísmo é de: "Amar o próximo como a si mesmo". (Levítico, 19:18)

Segundo o Rabbi Eliahu (1984), para o homem produzir prazer na mulher se faz necessário que ele saiba as diferenças naturais que existem entre eles no âmbito sexual. $\mathrm{O}$ homem tem o prazer mais rápido, enquanto que o prazer da mulher não está no ato em si, mas no carinho, no amor, nos beijos e tudo que envolve a antecede o ato, pois o ideal é o homem unir-se com sua esposa e os dois chegarem juntos ao climax.

Após o ato sexual o homem é proibido de abandonar sua esposa. Aconselha-se que o canal permaneça junto ao término da relação, demonstrando assim o afeto existente entre eles.

\section{CONCLUSÃO}

Observamos nesta pesquisa, a importância que o Judaísmo dá ao comportamento sexual para a manutenção don laços maritais.

O canal estaria sempre em lua-de-mel, sensação esta renovada mensalmente no reencontro do casal que fica "afastado sexualmente" durante o Período de Niddah, aumentando assim o diálogo e o desejo sexual.

Esses encontros são realizados no período mais fértil da mulher, o que demonstra a importância da procriação. Este dado deve ser analisado no contexto da história do povo que, enfrentando guerras e tentativas de extermínio, tem a necessidade do aumento da população. 
O importante é que mesmo havendo o intuito de procriação, não ocorre a desvinculação do desejo e do prazer.

Podemos observar em algumas religiões e crenças que este vínculo não se faz presente.

\section{BIBLIOGRAFIA}

1. ABRAMOV, Tehildo. O segredo da feminilidade judaica. São Paulo, Ed. Torá Colei, 1993. $174 \mathrm{p}$.

2. BAUMGARTEN, Dober. Villa Matrimonial Judaica. Buenos Aires, Ed. Amigos do Movimento Lubavitch de Buenos Aires. 64 p.

3. ELIAHU, Modechai. Darquei Taharat. Israel, Jerusalém, Ed. Sucat David, 1984. $220 \mathrm{p}$.

4. FRIEDMAN, Manis. Será que ninguém mais se envergonha? Recuperando a intimidade, a modéstia e a sexualidade. São Paulo, Ed. Maayanot, 1990. 151 p.

5. KAPLAN. Aryeh. As águas do Eden: $O$ mistério do Micvê. São Paulo, Ed. Maayanot, 1992, 143 p.

6. . Meditation and Kabbalab. USA Ed. Samuel Weiser, 1982. 355 p.

7. LAMM, Norman. Uma sebe de rosas. Visão judaica do sexo e do casamento. Rio de Janeiro, Ed. José Konfino, 1970. 68 p.

8. MATZLIAH, Meir. A Torá: A Lei de Moisés. Rio de Janeiro, Ed. Danúbio Sa., 1962. $510 \mathrm{p}$.

9. ZALMAN, Schneur. Likutei Amarim. São Paulo, Ed. Kerot do Brash, 1984. 387 p. 